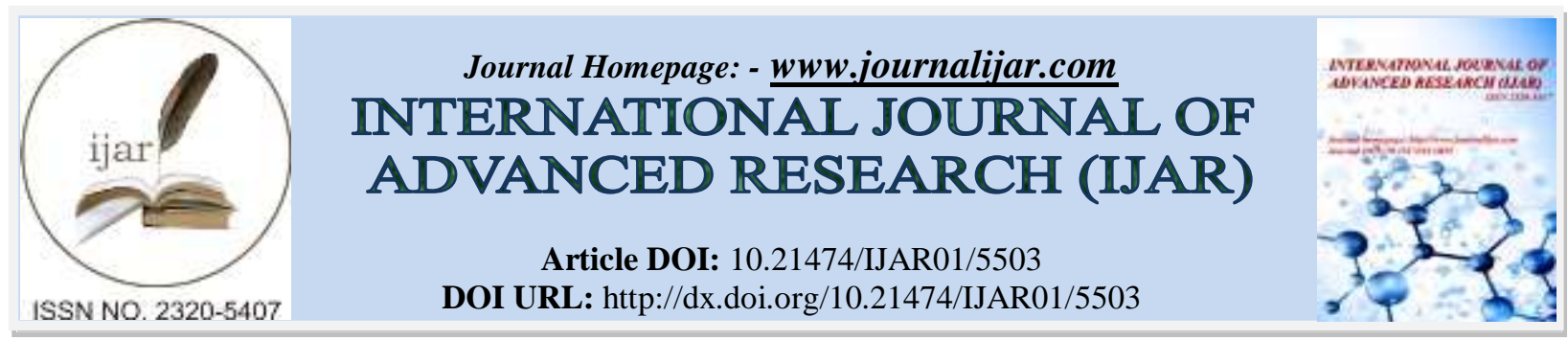

RESEARCH ARTICLE

\title{
GROWTH AND YIELD PERFORMANCE OF HOT PEPPER (Capsicum frutescens) FERTILIZED WITH FERMENTED PLANT MATERIALS.
}

Racoma, Avelino Detorio and Beato and Lolita Lovino.

Laguna State Polytechnic University, L. De Leon Street, Siniloan Laguna, Philippines.

\section{Manuscript Info}

Manuscript History

Received: 01 August 2017

Final Accepted: 03 September 2017

Published: October 2017

Key words:-

Fermented plant materials, hot pepper, banana pseudostem, wedelia (Wedelia trilobata) leaves, foliar fertilizers.

\begin{abstract}
A field experiment was conducted to determine the growth and yield performance of two hot pepper varieties using fermented plant materials as foliar fertilizers. A $2 \times 6$ factorial split plot design in randomized complete block design (RCBD) with four replications was employed. Factors included two hot pepper varieties $(\mathrm{A} 1=$ Pinatubo and $\mathrm{A} 2=$ Red Hot $)$ and five different plant sources for fermented plant juices (B2 = banana pseudostem + santing (Calopogonium muconoides) leaves, B3 = banana pseudostem + wedelia (Wedelia trilobata L.) leaves, B4 = banana pseudostem + acacia (Acacia seyal L.) leaves, B5 = banana pseudostem + madre de cacao (Gliricidia sepium Jacq.) leaves, and B6 = combination of all fermented plant juice materials. No fermented plant juice was applied on the control plants (B1).

Data indicated an interaction effect in terms of number of fruits per plant, weight of fruits per plant, and computed yield per hectare compared to the rest of the parameters which indicated no interaction effect. Red Hot variety obtained better performance in terms of number of days from transplanting to flowering and number of fruits per plant while Pinatubo variety performed better in terms of stem diameter per plant, length of fruits, weight of fruits and computed yield per hectare. Plants fertilized with banana pseudostem + wedelia (Wedelia trilobata) leaves as fermented plant juice gave the highest performance in terms of stem diameter and with interaction of variety and fertilizer in terms of weight of fruits per plant, computed yield per hectare. Pinatubo variety had the higher yield per hectare compared to Red Hot variety. Among the fermented plant materials evaluated, banana pseudostem + wedelia leaves has the best potential as nutrient source for organic hot pepper production.
\end{abstract}

Copy Right, IJAR, 2017,. All rights reserved.

\section{Introduction}

Hot pepper (Capsicum frutescens L.) or siling labuyo in the Philippines, is a perennial plant with small, tapering fruits often 2-3 at a node that are very pungent. Hot pepper is used generally as a condiment. Capsaicin, the active component of different types of hot peppers that makes the peppers spicy hot, are used as foods, pesticides, weight loss, topical anaesthetic and fighting indigestion (O’Dell 2012). When hot peppers are eaten or capsaicin is taken as a dietary supplement, the capsaicin may improve digestion by increasing the digestive fluids in the stomach and may 
also help fight diarrhea caused by bacterial infection. Capsaicin acts as an antioxidant, protecting the cells of the body from damage by harmful molecules called free radicals.

"Cultivating hot peppers in the Philippines is a good commercial opportunity not only for farmers, but also for agripreneurs who process fresh pods and seeds into finished products such as hot sauces, salsas, canned sardines, chocolates, and cookies" (Rappler 2017).

The passage of Philippine Republic Act 10068, otherwise known as the "Organic Agriculture Act of 2010" which promotes natural farming technology using indigenous materials such as fermented plant juices (FPJ) in agricultural production, entails the identification of various cost-effective, safe and eco-friendly sources of nutrients for organic crop production. The formulation and application of fermented plant juices, a mixture which can improve soil fertility and enhance growth. It is a mixture of chopped plant shoots or leaves and molasses that is fermented for a week or less and diluted to water. The mixture is then used as foliar fertilizer or drenched in to the soil (Buenaventura 2011; Miller et al 2013). As a natural growth enhancer-FPJ made from actively growing plant parts and fast growing plants may contain natural growth hormones and mineralized nitrogen that promotes plant growth. There is no overdose on the use ofFPJ ; it may be used liberally. However, the soil must be watered first before applying FPJ to avoid scorching of the roots (e-extension.gov.ph 2017).

Fermented plant juice provides more nitrogen to plants and enhances the ability of plants to photosynthesize better. It also gives additional phoshorus and helps plants absorb more phosphorus from the soil. Hence, the use of FPJ could promote vegetative growth and increase the volume and size of crops.

With this array of benefits, some locally available plant sources such as santing (Calopogonium muconoides), wedelia (Wedelia trilobata), acacia (Acacia seyal) and madre de cacao (Gliricidia sepium) leaves combined with banana pseudostem as alternative sources of nutrients for organically-grown hot pepper were used in this study. The potential of these plant leaves and saps as viable sources of nutrients and organic matter for the improved growth and development of hot pepper was explored in the present study. Now, there is a limited scientific investigations which focused on the impacts of fermented foliar fertilizer on crops, particularly on hot pepper. This study therefore, will determine which fermented liquid fertilizer from different plant sources will have the best potential with regard to its effect on the growth and yield performance of hot pepper.

\section{Materials And Methods:-}

The experiment was conducted in Brgy. Poblacion, Burdeos, Quezon, Philippines in 2014. Split plot design in randomized complete block design (RCBD) with four replications was employed. Factors included two hot pepper varieties $(\mathrm{A} 1=$ Pinatubo and $\mathrm{A} 2=$ Red Hot $)$ and five different plant sources for fermented plant juices $(\mathrm{B} 2=$ banana pseudostem + santing (Calopogonium muconoides) leaves, B3 = banana pseudostem + wedelia (Wedelia trilobata L.) leaves, B4 = banana pseudostem + acacia (Acacia seyal L.) leaves, B5 = banana pseudostem + madre de cacao (Gliricidia sepium) leaves, and B6 = combination of all fermented plant juice materials. No fermented plant juice was applied on the control plants (B1).

The soil analysis for the proximate soil nutrients available at the experimental area with respect to its physical, chemical and biological properties was done at the Bureau of Soils and Water Management (BSMW) in Diliman, Quezon City, Philippines. The experimental area was divided into two main plots. Each plot was subdivided into six sub-plots for the different plant sources as foliar fertilizers that were randomly assigned in plots of $3 \mathrm{~m} \times 4 \mathrm{~m}$ size. Hot pepper seeds, procured from East-West Seed Company [Red Hot F1] and Condor [Pinatubo F1], were sown in seedling trays with planting medium consisting of an equal proportion of garden soil, carbonized rice hull, sand and manure. Pricking of seedlings was done 25 days after sowing. Forty seven day-old hot pepper seedlings were transplanted in the experimental plots at a distance of $0.60 \mathrm{~m}$ by $0.45 \mathrm{~m}$. Preparation and fermentation of the foliar fertilizers was done two to three weeks prior to transplanting of hot pepper seedlings and the application of fermented foliar fertilizers was done weekly for ten consecutive weeks.

Data on growth characteristics and yield components were determined from ten experimental plants per treatment/plot. Fruit harvesting of hot pepper was carried out when the fruits were still green, but full-sized. The collected data on various parameters were statistically analyzed through analysis of variance (ANOVA) and the significance of differences among treatment means were compared by Duncan's Multiple Range Test (DMRT) with the aid of SAS system for Windows version 9.1. 


\section{Results and Discussions:- \\ Growth Parameters:- \\ Plant height:}

The heights of plants were measured from the ground level to the tip of the main shoot at 15, 30, 45, 60, 75 and 90 days after transplanting. As shown in Table 1, analysis of variance shows no interaction effect and no significant difference between varieties and among fertilizers. The results indicated that there was no significant difference on the responses of hot pepper varieties on different fertilizer materials in terms of plant height.

Table 1:- Plant height $(\mathrm{cm})$.

\begin{tabular}{|l|l|c|}
\hline Factors & Factor Levels & Mean \\
\hline Variety & & \\
\hline & Pinatubo & 59.21 \\
\hline & Red Hot & 58.92 \\
\hline Fertilizer & & 57.75 \\
\hline & B1 - Control - No Application & 58.88 \\
\hline & B2 - Banana pseudostem + santing (Calopogonium mucunoides) leaves & 60.00 \\
\hline & B3 - Banana pseudostem + wedelia (Wedelia trilobata) leaves. & 58.25 \\
\hline & B4 - Banana pseudostem + acacia (Acacia seyal) leaves. & 62.88 \\
\hline & B5 - Banana pseudostem + madre de cacao (Gliricidia sepium) leaves. & 56.63 \\
\hline & B6 - Combination of all FPJ materials. & \\
\hline \multicolumn{2}{|l}{$n s$ not significant } & \\
\hline
\end{tabular}

\section{Number of days from transplanting to flowering:-}

Pinatubo produced flowers 41.08 days after transplanting while Red Hot took 41.88 days to flower (Table 2). Data implies that Pinatubo variety bore flowers earlier than Red Hot variety. Results also indicate that hot pepper fertilized with banana pseudostem + madre de cacao leaves bore flowers ahead of the other treated and untreated plants, while the plants treated with combination of all FPJ materials took longer period to produce flowers, with a mean of 41.00 and 42.25 days, respectively. However, statistical analysis shows no interaction effect and no significant difference on fertilizers, but indicates a significant difference on varieties. Results of the present study conformed to the findings of Patil (1995) as cited by Yee (2014) that chilli plants applied with organic fertilizer resulted in early flowering.

Table 2:-Number of days from transplanting to flowering.

\begin{tabular}{|l|l|c|}
\hline Factors & Factor Levels & Mean \\
\hline Variety & & $41.08^{\mathrm{b}}$ \\
\hline & Pinatubo & $41.88^{\mathrm{a}}$ \\
\hline & Red Hot & 41.50 \\
\hline Fertilizer & & 41.25 \\
\hline & B1 - Control - No Application & 41.38 \\
\hline & B2 - Banana pseudostem + santing (Calopogonium mucunoides) leaves & 41.50 \\
\hline & B3 - Banana pseudostem + wedelia ( Wedeli atrilobata) leaves & 41.00 \\
\hline & B4 - Banana pseudostem + acacia ( Acacia seyal) leaves & 42.25 \\
\hline & B5 - Banana pseudostem + madre de cacao (Gliricidia sepium) leaves \\
\hline
\end{tabular}

\section{Stem Diameter (cm):-}

Data shows that Red Hot variety had greater stem diameter compared to Pinatubo variety with a mean of $1.17 \mathrm{~cm}$ and $1.03 \mathrm{~cm}$, respectively (Table 3). With regard to fertilizer sources, hot pepper fertilized with banana pseudostem + wedelia leaves and the combination of all FPJ materials produced greater stem diameter.

Analysis of variance shows no interaction effect but with significant difference among fertilizers and noted to have no significant difference between varieties.

DMRT indicates that application of banana pseudostem + wedelia leaves and combination of all FPJ materials, banana pseudostem + santing and banana pseudostem + acacia leaves can increase the stem diameter per plant. 
Table 3:- Stem diameter $(\mathrm{cm})$.

\begin{tabular}{|l|l|c|}
\hline Factors & Factor Levels & Treatment Mean \\
\hline Variety & & \\
\hline & Pinatubo & 1.03 \\
\hline & Red Hot & 1.17 \\
\hline Fertilizer & & $0.98^{\mathrm{b}}$ \\
\hline & B1 - Control - No Application & $1.14^{\mathrm{a}}$ \\
\hline & B2 - Banana pseudostem + santing (Calopogonium mucunoides) leaves & $1.16^{\mathrm{a}}$ \\
\hline & B3 - Banana pseudostem + wedelia (Wedelia trilobata) leaves & $1.13^{\mathrm{a}}$ \\
\hline & B4 - Banana pseudostem + acacia (Acacia seyal) leaves & $1.06^{\mathrm{b}}$ \\
\hline & B5 - Banana pseudostem + madre de cacao (Gliricidia sepium) leaves & $1.16^{\mathrm{a}}$ \\
\hline & B6 - Combination of all FPJ materials & \\
\hline \multirow{2}{*}{ * Means with same letter are not significantly different } & \\
\hline
\end{tabular}

Yield Parameters:-

Number of fruits per plant:-

Data in Table 4 shows that Pinatubo variety produced higher number of fruits compared to Red Hot variety with a mean of 63.50 and 58.38 , respectively.

Plants fertilized with banana pseudostem + madre de cacao leaves gave highest number of fruits per plant and hot peppers fertilized with the combination of all FPJ materials had the lowest number of fruits with a mean of 68.38 and 55.63, respectively. Analysis of variance shows interaction effect but no significant difference on varieties and fertilizers. DMRT showed that number of fruits of Pinatubo variety is significantly higher than Red Hot. Hot pepper fertilized with banana pseudostem + madre de cacao leaves produced the highest number of fruits per plant than the rest of the treatments.

This result conforms to the study of Tesfaw et al. (2013) which revealed that performance of hot pepper (Capsicum апnит) varieties is influenced by nitrogen and phosphorus fertilizer.

Table 4:- Number of fruits per plant.

\begin{tabular}{|c|l|c|c|}
\hline \multicolumn{2}{|c|}{} & \multicolumn{2}{c|}{ Mean } \\
\hline Factor & & Pinatubo (A) & Red Hot (B) \\
\hline Fertilizer & & & \\
\hline & B1 - Control - No Application & $50.75^{\text {ab }}$ & $67.75^{\text {ab }}$ \\
\hline & B2 - Banana pseudostem + santing (Calopogonium mucunoides) leaves & $62.00^{\text {ab }}$ & $56.00^{\text {ab }}$ \\
\hline & B3 - Banana pseudostem + wedelia (Wedelia trilobata) leaves & $72.25^{\mathrm{a}}$ & $48.50^{\mathrm{ab}}$ \\
\hline & B4 - Banana pseudostem + acacia (Acacia seyal) leaves & $64.50^{\mathrm{ab}}$ & $61.50^{\mathrm{ab}}$ \\
\hline & B5 - Banana pseudostem + madre de cacao (Gliricidia sepium) leaves & $62.50^{\mathrm{ab}}$ & $74.25^{\mathrm{a}}$ \\
\hline & B6 - Combination of all FPJ materials & $69.00^{\mathrm{a}}$ & $42.25^{\mathrm{b}}$ \\
\hline \multirow{2}{*}{$*$ Means with same letter are not significantly different } & & \\
\hline
\end{tabular}

\section{Length of Fruits (cm):-}

Data on Table 5 shows that Pinatubo variety produced longer fruits compared to Red Hot with a mean of 5.18 and 4.96 , respectively. Analysis of variance shows no interaction effect and no significant difference in fertilizers but noted to have significant difference between varieties.

DMRT also revealed that hot pepper fertilized with Banana pseudostem + acacia leaves produced the longest fruits followed by banana pseudostem + madre de cacao leaves, Control (no application) and combination of all FPJ materials, banana pseudostem + wedelia leaves, and banana pseudostem + santing leaves with a mean of 5.18, 5.11, $5.04,5.04,5.03$, and 5.01, respectively. 
Table 5:- Length of fruits per plant in $\mathrm{cm}$.

\begin{tabular}{|l|l|c|}
\hline Factors & Factor Levels & Mean \\
\hline Variety & & $5.18^{\mathrm{a}}$ \\
\hline & Pinatubo & $4.96^{\mathrm{b}}$ \\
\hline & Red Hot & \\
\hline Fertilizer & & 5.04 \\
\hline & B1 - Control - No Application & 5.01 \\
\hline & B2 - Banana pseudostem + santing (Calopogonium mucunoides) leaves & 5.03 \\
\hline & B3 - Banana pseudostem + wedelia (Wedelia trilobata) leaves & 5.18 \\
\hline & B4 - Banana pseudostem + acacia (Acacia seyal) leaves & 5.11 \\
\hline & B5 - Banana pseudostem + madre de cacao (Gliricidia sepium) leaves & 5.04 \\
\hline & B6 - Combination of all FPJ materials & \\
\hline
\end{tabular}

\section{Weight of fruits per plant (g):-}

Table 6 shows the weight of harvested fruits per plant. Heavier weight of fruits was noted on Pinatubo variety compared to Red Hot variety with a mean of 151.28 and 92.28 , respectively.

Statistical analysis shows interaction effect but no significant difference among varieties and fertilizer. DMRT also noted that Pinatubo hot pepper plants fertilized with banana pseudostem + Wedelia leaves produced heavier weight of harvested fruits while Red Hot pepper plants treated with the combination of all FPJ materials produced the lightest weight of fruits with a mean of $151.28 \mathrm{~g}$ and $81.98 \mathrm{~g}$, respectively.

The weight of the fruits per plant on the interaction effect of two varieties of hot pepper with the application of banana pseudostem + wedelia is significantly higher than the plant fertilized with combination of all FPJ materials. This conforms to the study of Fekadu and Dandena (2006) which indicated that the influence of genetic variability and heritability are necessary in systematic improvement of hot pepper varieties for fruit yield and related traits.

The variation in the yield among hot pepper varieties might be due to the genetic make-up, varying levels of fertilizers treatment and the nutrient status of the growing environment.

Table 6:-Weight of fruits per plant (grams)

\begin{tabular}{|c|l|c|c|}
\hline & & \multicolumn{2}{c|}{ Mean } \\
\hline & & $\begin{array}{c}\text { Pinatubo } \\
\text { (A) }\end{array}$ & $\begin{array}{c}\text { Red Hot } \\
\text { (B) }\end{array}$ \\
\hline Fertilizer & & & \\
\hline & B1 - Control - No Application & $99.30^{\text {ab }}$ & $126.63^{\text {ab }}$ \\
\hline & B2 - Banana pseudostem + santing (Calopogonium mucunoides) leaves & $122.28^{\mathrm{ab}}$ & $107.93^{\text {ab }}$ \\
\hline & B3 - Banana pseudostem + wedelia (Wedelia trilobata) leaves & $151.28^{\mathrm{a}}$ & $92.28^{\mathrm{b}}$ \\
\hline & B4 - Banana pseudostem + acacia (Acacia seyal) leaves & $126.33^{\mathrm{ab}}$ & $124.85^{\text {ab }}$ \\
\hline & B5 - Banana pseudostem + madre de cacao (Gliricidia sepium) leaves & $124.68^{\mathrm{ab}}$ & $144.48^{\mathrm{a}}$ \\
\hline & B6 - Combination of all FPJ materials & $139.18^{\mathrm{a}}$ & $81.98^{\mathrm{b}}$ \\
\hline$*$ Means with same letter are not significantly different & & \\
\hline
\end{tabular}

\section{Computed yield per hectare $(\mathrm{kg})$ :-}

Table 7 presents the computed yield per hectare. Data showed that Pinatubo variety had the higher yield per hectare compared to Red Hot variety. Analysis of variance shows interaction effect but no significant difference among varieties and fertilizers.

DMRT also noted that hot pepper fertilized with banana pseudostem + wedelia leaves produced highest yield while the combination of all FPJ Materials produced the lowest yield with a mean of $5603 \mathrm{~kg}$ and $3036 \mathrm{~kg}$, respectively. This follows the study of Romero (2014) which pointed out that in the process of farm conversion to organic farming; generally the yield of any crop will decline due to the reduction in the available major nutrients in the soil that will be supplied by organic fertilizer. 
Table 10:-Computed yield per hectare $(\mathrm{kg})$.

\begin{tabular}{|c|c|c|c|}
\hline & & \multicolumn{2}{|c|}{ Mean } \\
\hline & & $\begin{array}{c}\text { Pinatubo } \\
\text { (A) }\end{array}$ & $\begin{array}{c}\text { Red Hot } \\
\text { (B) }\end{array}$ \\
\hline \multicolumn{4}{|l|}{ Fertilizer } \\
\hline & B1 - Control - No Application & $3678^{\mathrm{ab}}$ & $4690^{\mathrm{ab}}$ \\
\hline & B2 - Banana pseudostem + santing (Calopogonium mucunoides) leaves & $4509^{\mathrm{ab}}$ & $3997^{\mathrm{ab}}$ \\
\hline & B3 - Banana pseudostem + wedelia (Wedelia trilobata) leaves & $5603^{\mathrm{a}}$ & $3417^{\mathrm{b}}$ \\
\hline & B4 - Banana pseudostem + acacia (Acacia seyal) leaves & $4678^{\mathrm{ab}}$ & $4623^{\mathrm{ab}}$ \\
\hline & B5 - Banana pseudostem + madre de cacao (Gliricidia sepium) leaves & $4617^{\mathrm{ab}}$ & $5350^{\mathrm{a}}$ \\
\hline & B6 - Combination of all FPJ materials & $5154^{\mathrm{a}}$ & $3036^{\mathrm{b}}$ \\
\hline \multicolumn{2}{|c|}{ * Means with same letter are not significantly different } & & \\
\hline
\end{tabular}

\section{Conclusion:-}

The performance of the two hot pepper varieties evaluated in the present study was affected by the different fermented plant materials used as foliar fertilizers. Pinatubo variety had the higher yield per hectare compared to Red Hot variety. Among the fermented plant materials evaluated, banana pseudostem + wedelia leaves has the best potential as nutrient source for organic hot pepper production.

\section{References:-}

1. Buenaventura CV and Bulong MP (2011). Community Based Participatory Action Research on Organic Vegetables Production Project (Annual Report Vegetable Farming-Bureau of Agricultural Research. Downloaded on January 21, 2014 at (http://www.bar.gov.ph/vegetablefarming).

2. Fekadu M and Dandena G (2006). Review of the Status of Vegetable Crops Production and Marketing in Ethiopia, Uganda J. Agric. Sci. 12(2):26-30. Downloaded on February $15 \quad 2015$ at (http://www.academicjournals.org/journal/...842C5B547).

3. Miller SA, Ikeda DM, Weinert EW, Chang KCS, Mc Ginn JM, Keliihoomalu C and DuPonte MW (2013). Natural Farming: Fermented Plant Juice. College of Tropical Agriculture and Human Resources. University of Hawaii at Manoa, Sustainable Agriculture 2013 S-7. Download on Feb.5, 2014 at (http://www.ctahr.hawaii.edu/oc/ freepubs/ pdf/SA-7.pdf).

4. O’Dell W (2012). Top 10 Uses for Hot Peppers, Food, Health, Nature (1-3) Download on Jan. 20,2014 at (http://www.toptenz.net/top-10-uses-for-hot- pepper-php).

5. Romero E (2014). Microbial Fertilizer for Increasing and Sustaining Rice Production on Organic Area and Area Under Conversion. International Journal of Scientific and Technology Research. Volume 3, issued 8, August 2014. ISSN 2277-8616.

6. Tesfaw A, Dechassa N and Sadik K (2013). Performance of Hot Pepper (capsicum annum) varieties as influence by Nitrogen and Phosphorus fertilizer at Bure, Upper Watershed of the Blue Nile, Northwest Ethiopia. Agricultural Sciences ISSN: 2167-0447 3 (8) : 599-608 October (2013. www.internationalschoolasjournal.org).

7. Yee L (2014). Performance of Three Varieties of Finger Pepper (Capsicum annum L.) Using Different Fertilizer Sources Under Upland Condition. Graduate Studies and Applied Research, Laguna State Polytechnic University, Siniloan, Laguna, Philippines. 